\title{
THE WATER QUALITY OF SOME SHALLOW WELLS FROM HARGHITA COUNTY (SÂDOMINIC COMMUNE), ROMANIA
}

\author{
SILVIA BURCĂ ${ }^{a}$, CERASELLA INDOLEAN ${ }^{a *}$
}

\begin{abstract}
This study includes the most important physico-chemical parameters monitoring of the shallow wells from Sândominic commune, Harghita County, Romania, in order to establish if the water sources can be used as drinking water. The $\mathrm{pH}, \mathrm{dH}$, acidity, alkalinity, $\mathrm{CCO}-\mathrm{Mn}, \mathrm{NO}_{2}{ }^{-}, \mathrm{NO}_{3}{ }^{-}$ - $\mathrm{NH}_{4}{ }^{+}, \mathrm{Cl}^{-}$and $\mathrm{Fe}_{\text {total }}$ parameters were determined using appropriate standard methods and compared with allowable values for drinking water, according to Romanian legislation. Based on the determined parameter values, most of the samples were characterized by a moderate or high mineralization (288-980 $\mathrm{mg} / \mathrm{L})$, and for some of them there was a contamination with organic substance and nitrate ions.
\end{abstract}

Keywords: groundwater, monitoring, shallow wells, pollution

\section{INTRODUCTION}

It is difficult to imagine any clean and sanitary environment without water. Invariably, the progress of sanitation throughout the world has been closely associated with the availability of water; and, the larger the quantity and the better the quality of the water, the more rapid and extensive has been the advance of public health.

Romania is a country with reduced water resources compared to the rest of Europe. Despite the achievement of numerous accumulations, the volume of surface water is modest and the rivers have a relatively small flow. Romania's total water resources are estimated at $40 \times 10^{9} \mathrm{~m}^{3} /$ year of which inland rivers have only $5 \times 10^{9} \mathrm{~m}^{3} /$ year and $3 \times 10^{9} \mathrm{~m}^{3} /$ year are groundwater. The water potential is approximately $1750 \mathrm{~m}^{3}$ / inhabitant / year, compared to the European average of $4800 \mathrm{~m}^{3} /$ inhabitant / year [1].

\footnotetext{
a Babeş-Bolyai University, Faculty of Chemistry and Chemical Engineering, Department of Chemical Engineering, 11 Arany Janos str., RO-400028, Cluj-Napoca, Romania

*Corresponding author e-mail: liliana.indolean@ ubbcluj.ro
} 
The water from Danube is used in small quantity (as water-source), but, even with this, the volume of Romanian water resources per capita remains modest compared to the average in Europe.

The water reserves differ geographically, being rich in mountain areas and low in Bărăgan and Dobrogea, as well as some karst areas, where the population uses even rainwater for some household needs. To reduce these discrepancies, various inter-basin adductions have been built, but they do not increase significantly the water amount, fact that make us have extrareasons to take care of Romanian water reserves, which is a problem not only quantitatively but also qualitatively [2-5].

The regulatory agency in the water sector in Romania is "Autoritatea Națională de Reglementare pentru Serviciile Comunitare de Utilități Publice" "National Romanian Regulator for Public Services" (ANRSC). As there was no more recent data available at a national level, a report published by ANRSC states that in 2011 a total number of 1021 entities were administrating water services [6], including mostly private 44 regional operators who accounted for $86,3 \%$ of the market share. The utilities usually manage all the existing stages of drinking water cycle, from abstraction, potable water treatment, transport and distribution to the collection, treatment and discharge of wastewater [7].

In Romania, on large areas, drinking water supply is represented by the groundwater, particularly from wells, more than $45 \%$ of the population lives in rural and benefit from centralized water supply system $[8,9]$.

Groundwater may contain impurities or contaminants, which can originate from watershed or soil. Water moving through underground rocks and soils may pick up magnesium, calcium, iron, manganese, chlorides, selenium, boron, arsenic or radon. Groundwater is often polluted due to human activities, such as: fertilizers usage, animal manures, pesticides, improperly built and located septic systems for household wastewater, storm-water drains that discharge chemicals to groundwater, improper disposal or storage of wastes, chemical spills at local industrial sites [10-12]. These natural contaminants can produce various health problems depending on their amount.

Oxidizable substances in water or chemical oxygen consumption are substances that can oxidize both cold and hot under the action of an oxidant (organic substances are oxidized hot and inorganic cold). The increase in the amount of organic substances in the water or their appearance at a given time indicates a water pollution with germs that usually accompany the organic substances $[8,9,13,14]$.

A special problem is generated by the presence of high nitrate/nitrite ions quantities. Ammonia results in water from the incomplete degradation of organic substances that contain nitrogen or may come from the soil. It represents the first stage of decomposition of organic substances with 
nitrogen content and therefore, indicates a recent pollution (hours, days) and consequently, is very dangerous. Nitrogen in water comes from incomplete oxidation of ammonia in the presence of nitrifying bacteria. They represent a more advanced stage of the decomposition processes of organic substances containing nitrogen and consequently, their presence or increase in concentration indicates an older pollution, so, less dangerous. The concomitant presence of ammonia and nitrite shows us a continuous pollution. The susceptibility to nitrite ions of new-born children and animals is due to the fetal hemoglobin, which has more affinity for oxygen, therefore forms methemoglobin, quicker than in adult organisms [15-21].

Iron can be found in water in the form of soluble ferric salts (in the ferrous form as bicarbonates and less as sulphates, phosphates or silicates), insoluble ferric salts (in the form of hydroxide) or in colloidal form, complexed with organic substances. Iron in water promotes the development of ferrobacteria, which obstruct the pipes. In excess, it gives the water a metallic taste, a reddish-brown colour, stains the laundry, it settles on the pipes, on the kitchen utensils, etc. [22, 23].

This paper includes a case study on the water quality from some shallow wells located in Sândominic commune, Harghita County, a place at the foot of the Hășmaș Mountains. In this commune there is no drinking water distribution network, it is obtained from wells.

\section{RESULTS AND DISCUSSION}

Sândominic commune is the largest commune in the Ciucu de Sus area, with a number of 6300 inhabitants.

The population density is high, the distance between the households being relatively small, there being no sewerage system for taking over the domestic water, the own pollution sources are close to the wells.

Evaluating the water samples collected from the wells from the commune perimeter, the following conclusions were reached: the water from the $\mathrm{W} 1$ is drinkable, but, there is probably still a drainage that achieves a partial communication with the Olt river, because a certain iron content was found in the samples taken from this well; the water from the W2 well is drinkable, with moderate to hard hardness, so it is necessary to add some water softener, when it is used for washing, to prevent the limescale deposition in the washing machine. In situations where it is desired to use water in the thermal power plant, it is advisable to add a cationic filter for calcium and magnesium ions retaining. 
The water from the W3 well is not drinkable, having a content above the limit allowed by the Romanian legislation in force for the chemical consumption of oxygen (presence of the organic substances) and, for the high content of $\mathrm{NH}_{4}{ }^{+} \mathrm{NO}_{3}{ }^{-}$and chloride ions, also. Exceeding these limits for the mentioned indicators can be attributed to the chemical fertilizer depot located in the vicinity of this well.

Based on water hardness, expressed in German degree, water can be classified as very soft $\left(0-4^{\circ} \mathrm{d}\right)$, soft $\left(4-8^{\circ} \mathrm{dH}\right)$, moderately hard $\left(12-18^{\circ} \mathrm{dH}\right)$, hard $\left(18-30^{\circ} \mathrm{dH}\right)$ and very hard $\left(>30^{\circ} \mathrm{dH}\right)[14,24]$.

Total hardness values, Table 1 and Table 2, showed that all well water samples have moderately hardness and can be included in the category of moderately hard. Values showed in Table 1 suggest that there are no major changes in this indicator for March compared to May. Higher hardness values were recorded for samples collected from the W2 area respectively W3 area, figure 1.

Table 1. The recorded values of surface water and well water quality indicators, for March 2020, Sândominic Commune, Harghita, Romania.

\begin{tabular}{|l|c|c|c|c|c|c|}
\hline Measured indicator & Olt & W1 & W2 & W3 & $\begin{array}{c}\text { Lunca } \\
\text { Mare }\end{array}$ & $\begin{array}{c}\text { Maximum } \\
\text { allowed } \\
\text { value } \\
\text { (law 458) }\end{array}$ \\
\hline $\mathrm{pH}$ & 7.4 & 6.6 & 7.0 & 7.0 & 6.8 & $6.5-8.5$ \\
\hline $\mathrm{CCO}-\mathrm{Mn}(\mathrm{mg} / \mathrm{L}) \mathrm{O}_{2}$ & 3.40 & 1.51 & 0.80 & $\mathbf{9 . 9 5}$ & 2.37 & $\mathbf{5 . 0}$ \\
\hline $\mathrm{NH}_{4}{ }^{+}(\mathrm{mg} / \mathrm{L})$ & $\mathbf{1 . 4 2}$ & 0 & 0 & 0.23 & 0.1 & $\mathbf{0 . 5}$ \\
\hline $\mathrm{NO}_{2}{ }^{-}(\mathrm{mg} / \mathrm{L})$ & 0.025 & 0 & 0 & 0 & 0 & 0.5 \\
\hline $\mathrm{NO}_{3}{ }^{-}(\mathrm{mg} / \mathrm{L})$ & 4.5 & 11 & 24 & $\mathbf{9 0}$ & $\mathbf{5 8}$ & $\mathbf{5 0}$ \\
\hline $\mathrm{Cl}^{-}(\mathrm{mg} / \mathrm{L})$ & 8.85 & 8.85 & 12.03 & 70.8 & 8.85 & 250 \\
\hline $\mathrm{Acidity}(\mathrm{mval} / \mathrm{ml})$ & 0.65 & 0.43 & 0.78 & 1.57 & 0.74 & - \\
\hline $\mathrm{Alkalinity,}(\mathrm{mval} / \mathrm{ml})$ & 2.94 & 2.52 & 5.26 & 10.09 & 2.52 & - \\
\hline $\mathrm{Hardness} \mathrm{d}^{0}$ & 12.10 & 9.36 & 18.5 & 18.5 & 11.42 & min. 5 \\
\hline Fetot $(\mathrm{mg} / \mathrm{L})$ & 0.95 & 0.1 & - & - & - & 0.2 \\
\hline Fixed residue $(\mathrm{mg} / \mathrm{L})$ & 225 & 288 & 420 & 980 & 301 & - \\
\hline
\end{tabular}


Table 2. The registered values of surface and groundwater water indicators for May 2020, Sândominic commune, Harghita, Romania.

\begin{tabular}{|l|c|c|c|c|c|c|}
\hline Measured indicator & Olt & W1 & W2 & W3 & $\begin{array}{l}\text { Lunca } \\
\text { Mare }\end{array}$ & $\begin{array}{l}\text { Maximum } \\
\text { allowed } \\
\text { value } \\
\text { (law 458) }\end{array}$ \\
\hline $\mathrm{pH}$ & 7.4 & 6.5 & 7.0 & 7.0 & 6.9 & $6.5-8.5$ \\
\hline $\mathrm{CCO}-\mathrm{Mn}(\mathrm{mg} / \mathrm{L}) \mathrm{O}_{2}$ & 3.50 & 1.50 & 0.85 & $\mathbf{1 0 . 0 5}$ & 2.30 & $\mathbf{5 . 0}$ \\
\hline $\mathrm{NH}_{4}{ }^{+}(\mathrm{mg} / \mathrm{L})$ & 1.76 & 0 & 0 & 0.38 & 0.13 & 0.5 \\
\hline $\mathrm{NO}_{2}^{-}(\mathrm{mg} / \mathrm{L})$ & 0.020 & 0 & 0 & 0 & 0 & 0.5 \\
\hline $\mathrm{NO}_{3}{ }^{-}(\mathrm{mg} / \mathrm{L})$ & 4.8 & 12 & 23.9 & $\mathbf{9 4}$ & $\mathbf{5 5}$ & $\mathbf{5 0}$ \\
\hline $\mathrm{Cl}^{-}(\mathrm{mg} / \mathrm{L})$ & 8.85 & 8.85 & 11.94 & 71.8 & 8.85 & 250 \\
\hline Acidity, $(\mathrm{mval} / \mathrm{ml})$ & 0.60 & 0.48 & 0.80 & 1.37 & 0.84 & - \\
\hline Alkalinity $(\mathrm{mval} / \mathrm{ml})$ & 2.64 & 2.02 & 5.00 & 10.29 & 2.78 & - \\
\hline Hardness d & 13.10 & 9.08 & 18.67 & 18.67 & 12.32 & min. 5 \\
\hline Fetot $(\mathrm{mg} / \mathrm{L})$ & 1.25 & 0.08 & - & - & - & 0.2 \\
\hline Fixed residue $(\mathrm{mg} / \mathrm{L})$ & 230 & 269 & 428 & 992 & 299 & - \\
\hline
\end{tabular}

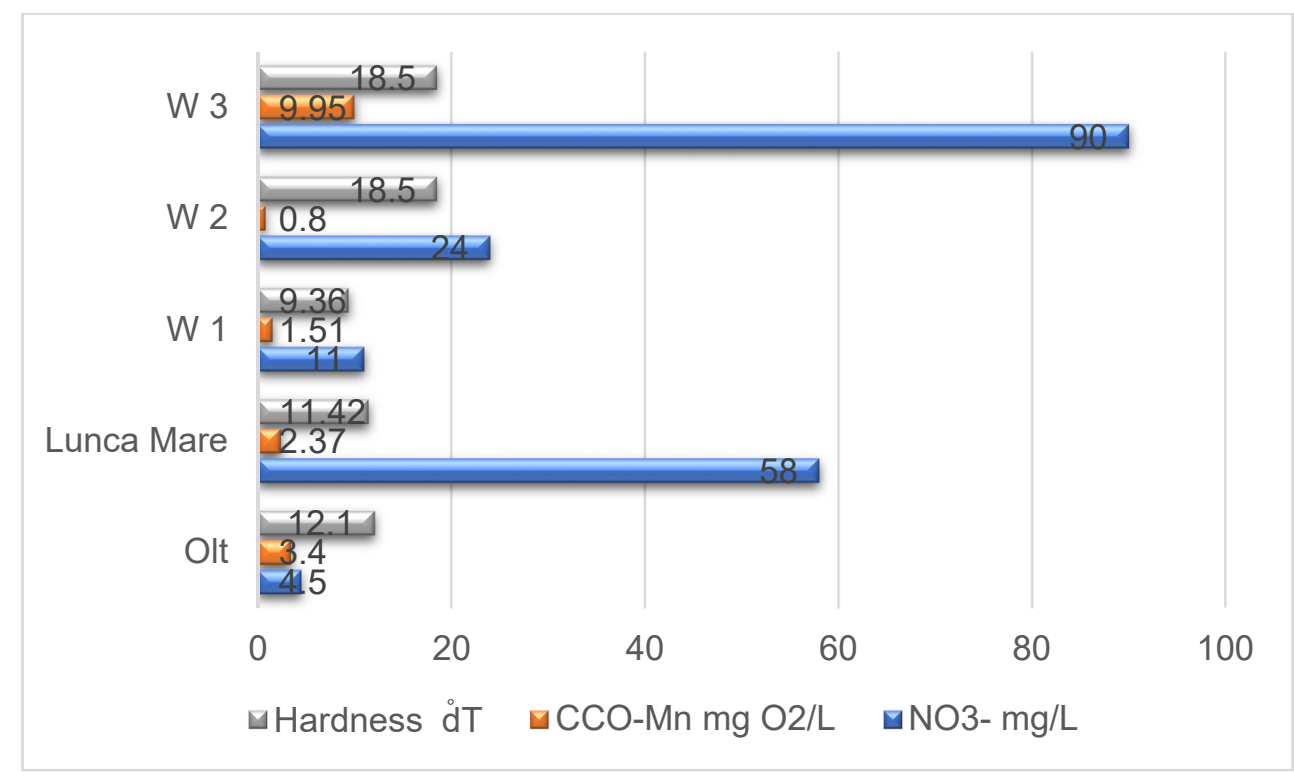

Figure 1. The CCO-Mn, total hardness and nitrate concentration values for the groundwater surface water samples - Sândominic Commune,

Harghita County, Romania, March 2020 
For the samples taken from the Olt River, it is found pollution from the waters of copper mines in the town of Balan, as well as a relatively high content of $\mathrm{NH}_{4}{ }^{+}$and $\mathrm{NO}_{3}{ }^{-}$ions (indicating a continuous pollution) and the presence of $\mathrm{Fe}_{\text {tot }}$ ions, also.

In addition, for the Lunca Mare River, the analysed samples suggest that there is a moderate pollution, due to the presence of organic substances and $\mathrm{NO}_{3}-$ ions, which is due to the discharge of untreated wastewater (from sewage).

\section{CONCLUSIONS}

Based on the monitoring of the physico-chemical properties carried out (the $\mathrm{pH}, \mathrm{dH}_{\mathrm{T}}$, acidity, alkalinity, $\mathrm{CCO}-\mathrm{Mn}, \mathrm{NO}_{2}^{-}, \mathrm{NO}_{2}^{-}, \mathrm{NH}_{4}{ }^{+}, \mathrm{Cl}^{-}$and $\mathrm{Fe}_{\text {total }}$ parameters) from samples taken (shallow well waters, Sândominic commune, Harghita County, Romania), it was found that, in general, the groundwater is characterized by a moderate to high mineralization (W3), but the water from this source isn't drinkable.

In the case of the water from the W2 well, this is drinkable, with moderate to hard hardness, so it is necessary to add some water softener, for household's consumption.

The water from the well W1 is drinkable, having a moderate hardness, but, the presence of the iron ions, probably due to an underground communication with the water from the Olt River, makes it not o superior and pleasant water to taste, so, of average quality for human consumption.

For the water samples taken from Olt River, there is a pollution of them with copper ions coming from mines in the nearby town of Balan and also, a relatively high content of $\mathrm{NH}_{4}{ }^{+}$and $\mathrm{NO}_{3}{ }^{-}$ions (indicating a continuous pollution), as well as the presence of $\mathrm{Fe}_{\text {tot }}$ ions.

Regarding the Lunca Mare River, there is a more moderate pollution, the presence of organic substances and $\mathrm{NO}_{3}{ }^{-}$ions is due to the discharge of untreated domestic waters.

\section{EXPERIMENTAL SECTION}

\section{Collection site and water sampling}

The water samples were collected from wells (Figure 2) located in Sândominic, Harghita County, Romania, in March and May 2020. 


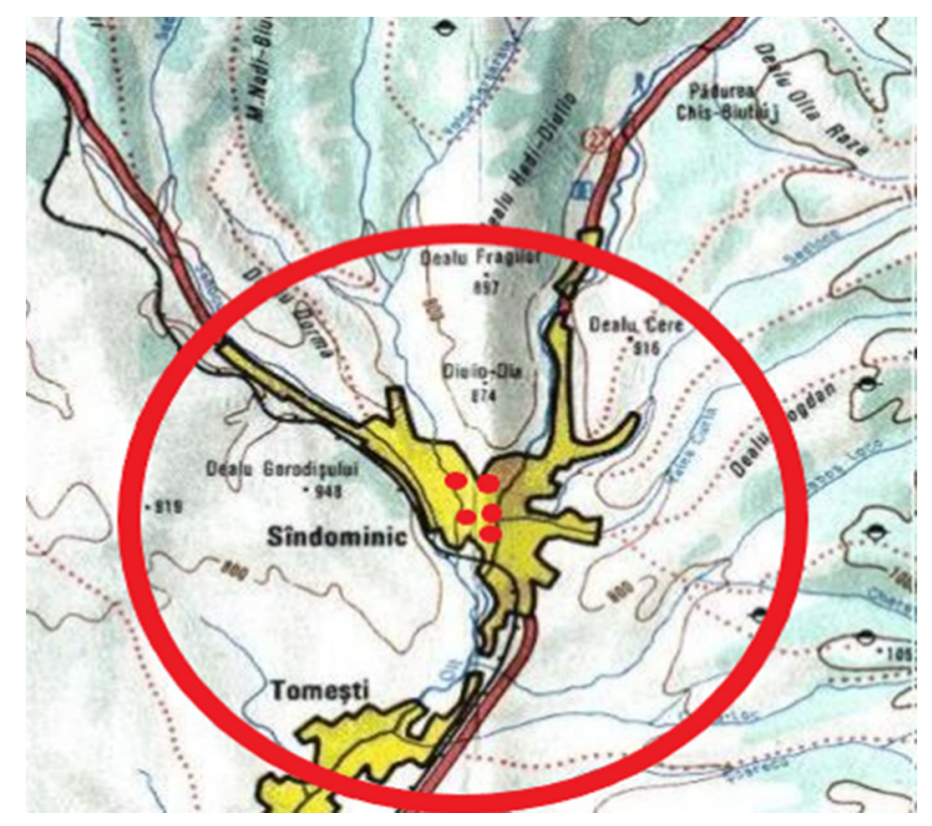

Figure 2. Sândominic commune, Harghita County, Romania; the water sampling points [26].

Sândominic commune is located at the intersection of latitude $46^{\circ} 35$ $\mathrm{N}$, with the length of $25^{\circ} 48 \mathrm{E}$, at $640 \mathrm{~m}$ above sea level. Specific to this region is the mountainous relief whose elevations vary between $840 \mathrm{~m}$ in the Olt Valley and $1792 \mathrm{~m}$ in the peak of Hășmașu Mare [25].

The mesometamorphic complex and the sedimentary rock system of the Hășmașu Mare massif

The western part is dominated by a high relief coming from the Neogene volcanic eruptions, made up of the Gurghiu and Harghita massifs, with characteristic volcanic morphology [28].

In this area the relief forms heights that reach up to $1800 \mathrm{~m}$. In the crystalline-Mesozoic area, at the eastern limit of the perimeter, a rugged relief with steep slopes is specific. In the mesometamorphic lens, the rugged terrain forms are maintained, while in the epimetamorphic complex the aspects become more attenuated, with small variations in altitude. The contrast of the epimetamorphic-mesometamorphic lands can be observed conclusively on the Olt Valley [25-28]. 


\section{Climate}

The region is characterized by a temperate subalpine continental climate, with an average annual temperature of $5-6^{\circ} \mathrm{C}$, The winds are closely related to major atmospheric circulations and relief conditions. Winds generally blow from the northwest, and spring and autumn are easterly, sometimes southerly winds [29].

\section{Hydrography}

Hydrographically, the region belongs to the upper basin of the Olt hydrographic network. The subalpine climate with relatively abundant annual precipitation determined the formation of a dense hydrographic network, characterized by small watercourses, with variable flow, but generally low. The flow of watercourses varies depending on the precipitations level. The hydrographic network is tributary to the Olt River, which has as main tributaries from the west: Szanduj brook, Sipos brook with Virgo tributaries, Jindieșul de Sus, Jindieșul de Jos, Ruțoc, Minei stream, Salamaș stream, Vărășoaia brook with tributaries Magasbukk, Voroc, Fagul Cetății Mici, Fagul Cetății Mari and Drumul Coastei [30].

It can be appreciated that the network in the western part is less developed than in the eastern part (despise the mesozone), where the water flows are higher. The tributaries from this zone are: Meggyes stream (with Vaspatak, Csofronkako, Csofronka tributaries), Nagyag stream, Mesteacăn stream, Szekpataka stream (with Gyengemenes tributary), Kovacs stream, Mihaly stream, Szimina stream, Galkut, Borviz, Szabók and Kurta stream. The rest of the valleys are torrential, with intermittent watercourses [26-30].

The groundwater samples were taken between the Olt River and Lunca Mare from Sândominic commune, and the surface water samples were taken from the Olt River and Lunca Mare stream.

Sources of groundwater and surface water pollution in Sâdominic commune

The main pollution sources for groundwater in Sândominic commune are: wastewater from septic tanks in households, the location of stables, latrines, landfills are located at a relatively short distance from wells, the existence of a chemical fertilizer depot.

For surface waters (Olt and Lunca Mare) the main sources of pollution are: wastewater resulting from the industrial technological process at copper mines (operated until 2006 in Balan city), the location of stables, latrines, landfills too close to the river Olt and Lunca Mare stream and meteoric waters.

Water samples were taken from wells located in the following areas: Sândominic no.1016 area (W1), Marton Aron General School (W2) and Gall 
Sândominic no.1693 area (W3). The fountains have a depth between 6 and $8 \mathrm{~m}$, the water depth in the fountain is $1-2.5 \mathrm{~m}$, the variation of the water level after precipitation is $30-40 \mathrm{~cm}$ - for the fountain located on W1 and 4-5 cm for the fountain located in the W3 area. The distance to the nearest source of pollution is between $9-15 \mathrm{~m}$, see table 3 .

Water samples were collected in plastic containers, previously rinsed 2-3 times with the water sample, completely filled, and then closed so that no air bubbles remain inside the bottle. On wells equipped with pumps, the water sample was collected after a minimum of 10 minutes run, while from wells with extraction the samples collection was made introducing the bucket at $10-30 \mathrm{~cm}$ below the water mirror. After collection, bottles were placed in dark boxes.

Until the analyses were run water samples were kept at temperatures below $5^{\circ} \mathrm{C}$ and processed within $6 \mathrm{~h}$ from collection.

Table 3. The characteristics of the groundwater source.

\begin{tabular}{|l|c|c|c|c|}
\hline $\begin{array}{c}\text { Well water } \\
\text { samples }\end{array}$ & $\begin{array}{c}\text { Depth well } \\
(\mathbf{m})\end{array}$ & $\begin{array}{c}\text { Depth of the } \\
\text { water in the well } \\
(\mathbf{m})\end{array}$ & $\begin{array}{c}\text { Variation of water } \\
\text { level after } \\
\text { precipitation } \\
(\mathbf{c m})\end{array}$ & $\begin{array}{c}\text { Distance to the } \\
\text { nearest source of } \\
\text { pollution } \\
(\mathbf{m})\end{array}$ \\
\hline W1 & 7 & 2.5 & $30-40$ & 15 \\
\hline W2 & 8 & 2 & - & 9 \\
\hline W3 & 6 & 1 & $4-5$ & 15 \\
\hline
\end{tabular}

Water samples analysis

For the collected water samples, the following indicators were determined: the $\mathrm{pH}$, acidity, alkalinity, total hardness, ammonia concentration, nitrite concentration, nitrate concentration, chemical oxygen consumption, iron ion concentration, $\mathrm{Cl}^{-}$ion concentration and the fixed residue.

Wells water samples were characterized using the physico-chemical methods according to Romanian legislation (Laws 458/2002, 311/2004).

The $\mathrm{pH}$ were determined using a Consort $\mathrm{C} 863 \mathrm{pH}$ meter (SR ISO 10523/96), total dissolved solids (TDS) were determined using gravimetric method (Romanian STAS 3638/76). Total hardness and chemical oxygen demand were determined by volumetric method (Romanian STAS 3326-76, STAS 3002-85). Concentration of $\mathrm{Fe}_{\text {total, }} \mathrm{NO}_{2}{ }^{-} \mathrm{NO}_{3}{ }^{-}$and $\mathrm{NH}_{4}{ }^{+}$ions were determined using molecular absorption spectroscopy (SR 13315/96, STAS 3048/2-96, SR ISO 7890-3:2000, STAS 6328/85) using an UV VIS Spectrometer Jenway 6305.

Each sample was measured three times, the averaged values were presented. 


\section{REFERENCES}

1. A. Cineti; "Resursele de ape subterane ale României", Ed. Tehnica, București, 1999, pp. 296-299.

2. M. Mănescu; "Poluarea apelor subterane: studii de caz", Ed. Orizonturi Universitare, Timișoara, 2002, pp. 240-251.

3. S. Manescu; M. Cucu; M. L. Diaconescu; "Chimia sanitară a mediului”, Ed. medicală, București, 1994, pp. 40-158.

4. M. Chiba; A. Sinohara; M. Sekine; J. Radioanal. Nucl. Chem., 2006, 269, 519526.

5. Ordin nr. 161 din 16/02/2006 pentru aprobarea Normativului privind clasificarea calităţii apelor de suprafaţă în vederea stabilirii stării ecologice a corpurilor de apă.

6. Autoritatea Națională de Reglementare pentru Serviciile Comunitare de Utilități Publice - Raport de activitate, 2013.

7. A. Delcea, I. Bitir-Istrate, R. Pătrașcu, C. Gheorghiu, E3S Web of Conferences 85, 06008 (2019), EENVIRO 2018, 2019, 1-15.

8. M. Sabio; F. Zamora; J. Gañan,; C.M. González-García; J.F. González; Water Res., 2006, 40, 3053-3060.

9. Y.S. Li; Arch. Environ. Contam.Toxicol., 1996, 31, 557-562.

10. S. Cater; M. Stefan; J. Bolton; A. Safarzadeh-Amiri; Environ. Sci. Technol., 2000, 34, 659-662.

11. Y. Ranran; C. Baoshan; Procedia Environ. Sci., 2010, 2, 1745-1749.

12. M.A. Barron; L. Haber; A. Maier; J. Zhao; M.Burron; "Toxicological review of phenol" EPA/635/R-02/006, 2002.

13. M. Stanca; A. Măicăneanu; C. Indolean; "Caracterizarea, valorificarea şi regenerarea principalelor materii prime din industria chimică şi petrochimică, Ed. Presa Universitară Clujeană, Cluj-Napoca, 2007, pp. 6-28.

14. S. Burcă, C. Indolean, A. Măicăneanu, Studia UBB Chem., 2015, 3(3), 247-255.

15. M. Ielenicz; "Dealurile şi podişurile României”, Editura Fundaţiei „România de mâine", București, 1999, pp. 34-167.

16. C. Baciu; "Hidrogeologie. Elemente teoretice şi aplicaţii practice", Ed. Cărţii de Ştiinţă, Cluj-Napoca, 2004, pp. 151-158.

17. N. Mészáros; O. Clichici; "Pe poteci cu bănuţei de piatră: ghid geologic al zonei Cluj", Ed. Tipored, București, 1967, pp. 60-68.

18. M. Tokumura; A. Ohta; H. Znad; Y. Kawase; Water Res., 2006, 40, 3775-3784.

19. J. Casado,;J. Fornaguera; M.I. Galán; Water Res., 2006, 40, 2511-2516.

20. Z. Kassam; L. Yerushalmi; S. Guiota; Water, Air, \& Soil Pollution, 2003, 143, 179-192.

21. Sanchez-Polo; J. Rivera-Utrilla; U. Gunten; Water Res., 2006, 40, 3375-3384.

22. World Healt Report 2007, "A safer future: global public health security in the $21^{\text {st }}$ century", World Health Organization, 1211 Geneva 27, Switzerland.

23. C. Nertan; C. Rosu, Environ. Prog., 2010, 12, 293-298. 
24. B. Almăşan, et col., Studiu complex al condiţiilor geologice şi minerale ale zăcământului pirito-cuprifer de la Bălan, în vederea optimizării metodelor de exploatare". Universitatea Bucureşti, 1986, pp. 3-48.

25. I.S. Atanasiu; "Cercetări geologice în împrejurimile Tulgheşului”; Anuarul I.G.al R.S.R., vol. XIII, 1928.

26. www.carpati.org_harta_muntii_Hasmas_83_LI

27. I.Băncilă; "Geologia Carpaţilor Orientali"; Ed. St. Bucureşti; 1958.

28. I. Bercia; E. Bercia; H.G. Krautner; "Unităţ̧ile tectonice structurale şi stratigrafice a formaţiunilor metamorfice din zona Cristalino-mezozoică a Munţilor Bistriţei"; D.S. vol III/1, 1996.

29. A. Chelărescu; "Note sur legisement cuprifere Bălan. (Transylvanie)"; C.R.Inst. des Sci.Romanie, Acad. Des Sci III./2, 1939.

30. D. Codarcea; ,Noi date asupra stratigrafiei terenurilor cristalofiliene din România"; Studii şi cercetări Tom.12 Bucureşti, 1967. 
